DOI: $10.25140 / 2411-5215-2020-1(21)-229-237$

Людмила Мекшун, Максим Забаштанський

\title{
ФІНАНСОВЕ ЗАБЕЗПЕЧЕННЯ СТИМУЛЮВАННЯ РОЗВИТКУ ТРУДОВОГО ПОТЕНЦІАЛУ В УМОВАХ АКТИВІЗАЦІЇ МІГРАЦІЙНИХ ПРОЦЕСІВ
}

\author{
Людмила Мекшун, Максим Забаштанский \\ ФИНАНСОВОЕ ОБЕСПЕЧЕНИЕ СТИМУЛИРОВАНИЯ РАЗВИТИЯ \\ ТРУДОВОГО ПОТЕНЦИАЛА В УСЛОВИЯХ АКТИВИЗАЦИИ \\ МИГРАЦИОННЫХ ПРОЦЕССОВ \\ Liudmyla Mekshun, Maksym Zabashtanskyi

\section{FINANCIAL PROVISION OF STIMULATION OF LABOR POTENTIAL DEVELOPMENT IN THE CONDITIONS OF ACTIVATION OF MIGRATION PROCESSES}

У статті проаналізовано сучасний стан та перспективи розвитку фінансового забезпечення трудового потенціалу в Украӥні. Проведено порівняльний аналіз фінансового забезпечення стимулювання праці в провідних краӥнах світу, згруповано фактори стимулюючого та обмежуючого впливу на стан трудового потенціалу крайни. Визначено, щчо ключовими проблемами, щчо заважають розвитку трудового потенціалу в країни є низький рівень функціонування національної економіки, пов'язаний зі значним відставанням технологічних можливостей, моральним та фiзичним зноченням основних засобів, неможливістю створення інноваційного продукту з високою доданою вартістю, щз спричиняе низьку продуктивність прачі.

Обтрунтовано, що з метою розвитку національної економіки, ключовою умовою є створення високотехнологічного виробництва, здатного забезпечити конкурентоспроможність власної продукції на світовому ринку, щчо можливо здійснити лише за умови належного фінансового забезпечення стимулювання розвитку трудового потенціалу. Доведено, що належне фінансове забезпечення стимулювання праці повинно виступити ключовою умовою генерації та збереженню трудового потенціалу необхідного для результативного функиіонування національної економіки.

Ключові слова: фінанси; фінансові ресурси; фінансове забезпечення; трудовий потенціал; стимулювання розвитку трудового потенціалу; фінансові важелі.

Табл.: 5. Бібл.: 12.

В статье проанализировано современное состояние и перспективы развития финансового обеспечения трудового потенциала в Украине. Проведен сравнительный анализ финансового обеспечения стимулирования труда в ведущиих странах мира, сгруппированы факторы стимулирующего и ограничивающего влияния на состояние трудового потенцчиала страны. Определено, что ключевыми проблемами, которые ограничивают развитие трудового потенциала в стране, является низкий уровень развития национальной экономики, связанный со значительным отставанием технологических возможностей, моральным и физическим износом основных средств, невозможностью создания инновационного продукта с высокой добавленной стоимостью, что вызывает низкую производительность труда.

Обосновано, что в целях развития национальной экономики, ключевым условием является создание высокотехнологичного производства, способного обеспечить конкурентоспособность своей продукиии на мировом рынке, что возможно осуществить только при условии надлежащего финансового обеспечения стимулирования развития трудового потенциала. Доказано, что надлежащее финансовое обеспечение стимулирования труда должно выступить ключевым условием генерации и сохранению трудового потенциала необходимого для результативного функчионирования национальной экономики.

Ключевые слова: финансы; финансовые ресурсы; финансовое обеспечение; трудовой потенциал; стимулирование развития трудового потенциала; финансовые рычаги.

Табл.: 5. Библ.: 12.

The article analyzes the current state and prospects of financial development of labor potential in Ukraine. The comparative analysis of financial support of labor stimulation in the leading countries of the world is carried out, the factors of stimulating and limiting influence on a condition of labor potential of the country are grouped. It is determined that the key problems hindering the development of labor potential in the country are the low level of development of the national economy, associated with a significant backlog of technological capabilities, moral and physical depreciation of fixed assets, the inability to create an innovative product with high added value.

It is substantiated that in order to develop the national economy, the key condition is the creation of high-tech production that can ensure the competitiveness of its own products on the world market, which can be done only with adequate financial support to stimulate labor potential. It is proved that adequate financial support for labor incentives should be a key condition for the generation and preservation of labor potential necessary for the effective functioning of the national economy.

Keywords: finances; financial resources; financial support; labor potential; stimulating the development of labor potential; financial leverage.

Tables: 5. References: 12.

JEL Classification: G20; G23; G40 
ФІНАНСОВІ РЕСУРСИ: ПРОБЛЕМИ ФОРМУВАННЯ ТА ВИКОРИСТАННЯ

Постановка проблеми. Підвищення рівня життя суспільства, інноваційний розвиток реального сектору економіки, забезпечення високих соціальних стандартів життєдіяльності $€$ наріжним каменем функціонування будь-якої держави, яка прагне забезпечити конкурентоспроможність національної економіки, зростання рівня добробуту населення.

Проте в сучасних умовах національна економіка має суттєві проблеми, які заважають iï розвитку, зокрема, іiї належність до III - IV технологічного укладу, що визначає рівень взаємозв'язку виробництва та економічних відносин. Суттєве технологічне відставання національної економіки від провідних країн світу унеможливлює їі конкурентоспроможність, що спричиняє наявність значних дисбалансів секторального розвитку, сприяє трудовій міграції та поглиблює соціальні незадоволення, що загалом має сукупний вплив на формування реальної загрози для економічної безпеки держави.

Таким чином, сталий розвиток вітчизняної економіки, виражений у ії інноваційному спрямуванні, неможливий без динамічних процесів розвитку та збереження трудового потенціалу підкріплених їх належним фінансовим забезпеченням. Саме визначення та гарантування достатнього рівня фінансового забезпечення є ключовим інструментом збереження трудових ресурсів та розвитку трудового потенціалу в країні.

Аналіз останніх досліджень та публікацій. Питання фінансового забезпечення стимулювання та розвитку трудового потенціалу розглядали в своїх працях такі відомі науковці, як І. Канцур, О. Кириленко, І. Кичко, А. Кузнецов, Л. Кривенко, Е. Лібанова, Г. Мамонова, Д. Нехайчук, С. Онишко, Г. Румянцева, О. Ціжма, Р. Чорний, С. Шкарлет та інші.

Виділення недосліджених частин загальної проблеми. Незважаючи на значну кількість фундаментальних досліджень, проведених із цієї теми, є необхідність подальшого вивчення особливостей фінансового забезпечення стимулювання розвитку трудового потенціалу 3 урахуванням новітніх тенденцій як однієї 3 ключових умов призупинення темпів трудової міграції населення, а також провідного фактору реалізації потенційних можливостей інноваційного розвитку національної економіки.

Отже, метою цього дослідження $є$ висвітлення проблемних питань фінансового забезпечення стимулювання розвитку трудового потенціалу в умовах активної міграції трудового населення та низького рівня технологічного розвитку національної економіки.

Виклад основного матеріалу. Питання фінансового забезпечення стимулювання розвитку трудового потенціалу перебувають у площині підвищеної уваги науковців та практиків, що зумовлено, з одного боку, необхідністю його збереження, а з іншого - високим рівнем безробіття, дисбалансом на ринку праці та відсутністю належного рівня оплати праці, достатнього для задоволення базових потреб життєдіяльності суспільства.

Нині немає одностайного трактування категорії «фінансове забезпечення стимулювання розвитку трудового потенціалу», що дозволяє сформулювати авторське трактування досліджуваної дефініції як відносини щодо формування та розподілу обсягу фінансових ресурсів, достатніх для повного забезпечення потреб життєдіяльності трудових ресурсів, формування та розвитку необхідних знань та вмінь, спрямованих на виконання необхідних завдань, забезпечення інноваційного розвитку національної економіки.

Саме відсутність належних умов залучення трудового потенціалу виступає причиною значної міграції трудових ресурсів. У сучасному світі міграційний рух досягає дедалі більшого масштабу, особливістю якого є те, що потоки мігрантів спрямовуються не тільки 3 менш розвинених до більш розвинених економік, але й виникають між країнами з приблизно однаковим рівнем економічного розвитку. Легкий перетин кордону чи повне скасування митних процедур сприяє формуванню нових міграційних переміщень.

Виділяють кількісні та якісні фактори, що визначають формування трудового потенціалу. До кількісних відносять: чисельність працездатного населення; чисельність і структуру зайнятого населення; чисельність безробітних; кількість робочого часу, відп- 
рацьованого працездатним населенням, або такого, який може бути відпрацьованим; рівень народжуваності; статеву та вікову структуру населення. До якісних факторів належать: трудова активність; схильність працездатних осіб до мобільності; трудова міграція; психофізіологічна працездатність; рівень культури та моральна зрілість; загальноосвітній та професійно-кваліфікаційний рівень.

Таким чином, трудова міграція є одним із якісних факторів, які впливають на трудовий потенціал країн. Зовнішня трудова міграція залежить від багатьох факторів. Згідно 3 дослідженнями Е. Лі всі фактори можна умовно розділити на фактори «відштовхування» та «притягання», таблиця 1 [1].

Таблиця 1

Фактори впливу на зовнішню трудову міграчіюю

\begin{tabular}{|c|c|}
\hline Фактори «притягання» & Фактори «відштовхування» \\
\hline \multicolumn{2}{|c|}{ Економічні } \\
\hline - високий рівень доходів; & - низький рівень доходів; \\
\hline - високий рівень життя; & - низький рівень життя; \\
\hline - стабільний розвиток економіки; & - економічна нестабільність; \\
\hline - ліберальна і прозора система оподаткування; & - обтяжлива і непрозора система оподаткування; \\
\hline - наявність робочих місць. & - відсутність робочих місць. \\
\hline \multicolumn{2}{|c|}{ Соціальні } \\
\hline - гарні умови праці; & - погані умови праці; \\
\hline - висока якість освіти; & - низька якість освіти; \\
\hline - високоякісна та доступна медицина; & - низька за якістю та малодоступна медицина; \\
\hline - наявність можливостей для самореалізації. & - відсутність можливостей для самореалізації. \\
\hline \multicolumn{2}{|c|}{ Політичні } \\
\hline - розвинена демократія і свобода слова; & - відсутність демократії, утиск свободи слова; \\
\hline - відсутність корупції; & - корумпованість влади; \\
\hline - стабільність політичної системи. & - нестабільність політичної системи. \\
\hline \multicolumn{2}{|c|}{ Культурні } \\
\hline - свобода віросповідання; & - релігійні переслідування; \\
\hline - відсутність етнічної дискримінації; & - наявність етнічної дискримінації; \\
\hline - відсутність расової дискримінації; & - расова дискримінація. \\
\hline \multicolumn{2}{|c|}{ Екологічні } \\
\hline - чиста питна вода та екологічна їжа; & - неякісна питна вода та їжа; \\
\hline - аадовільний екологічний стан. & - незадовільний екологічний стан \\
\hline
\end{tabular}

Джерело: побудовано авторами на основі [1].

Зовнішня трудова міграція в Україні є реакцією населення на негативні зміни в соціально-економічному розвитку національної економіки. На сучасному етапі внутрішніми чинниками, які спричиняють виїзд вітчизняних трудових ресурсів за кордон з метою працевлаштування, $є$ :

- низький рівень фінансового забезпечення працівників, порівняно з розвиненими країнами;

- довготривале безробіття та зниження попиту на робочу силу в окремих регіонах;

- невідповідність між рівнем оплати праці та вартістю життя в країні;

- безробіття та зниження рівня життя населення;

- тінізація певного сектору ринку праці в Україні тощо.

До зовнішніх чинників належать: зростання попиту на низько кваліфіковану працю в будівництві, сільському господарстві, сфері послуг у більшості країн Європи, які не задовольняються власною робочою силою; значно вищі рівні оплати праці, ніж в Україні та вигідніші умови працевлаштування; наявність нелегальних форм трудової міграції (в Греції, Іспанії, Італії, Португалії, Німеччині, країнах Східної Свропи) та ін. 
ФІНАНСОВІ РЕСУРСИ: ПРОБЛЕМИ ФОРМУВАННЯ ТА ВИКОРИСТАННЯ

Саме тому українські трудові мігранти виїжджають за кордон в пошуках роботи, очікуючи високого рівня доходів, ліберальної і прозорої системи оподаткування, наявності можливостей для самореалізації.

Точні дані про обсяги, структуру та напрями зовнішньої трудової міграції в Україні практично відсутні через складнощі з організацією збору даних про трудових мігрантів, їхні доходи та працевлаштування. За даними Міністерства соціальної політики України у 2018 році компанії, які мають ліцензію на посередництво в працевлаштуванні за кордоном, оформили на роботу за кордоном 97098 українських трудових мігрантів. Більшість iз них поїхала працювати до Кіпру (19 243 особи), Польщі (12 539 осіб), Німеччини (10 558 осіб) та Великої Британії (7890 осіб). Для порівняння: у 2017 році легально працевлаштувалося за кордоном 83779 українців. Хоч Кіпр і не входить у шенгенську зону, але активно використовує дешеву робочу силу, надаючи мігрантам можливість перебувати в країні протягом 90 днів. Також значна кількість трудових мігрантів працевлаштувалася за кордоном самостійно. За даними Державної прикордонної служби та Державної міграційної служби, на постійній основі за кордоном працює 3,2 млн українців, а під час сезонних робіт у сільському господарстві їх кількість зростає до 4,5 млн осіб [2].

Як зазначає О. Кваша, середній вік українських трудових мігрантів становить 34 роки. Серед осіб віком 18-44 роки довготермінова міграція становить $71 \%$. Люди, старші за 45 років, більше беруть участь у короткостроковій трудовій міграції. Українські трудові мігранти становлять $37 \%$ серед мігрантів із завершеною вищою освітою. Відбувається «відплив мізків», оскільки виїжджають за кордон інженери, фахівці з ITтехнологій, лікарі, науковці [3].

За даними Свропейського бюро статистики (Свростат), українські трудові мігранти переважно зайняті в таких секторах економіки: будівництво - 46 \%, домашній догляд $18 \%$, оптова і роздрібна торгівля - $9 \%$, сільське господарство - $11 \%$, промисловість $4 \%$, діяльність готелів і ресторанів - $4 \%$, діяльність транспорту і зв'язку - $4 \%$, інші види економічної діяльності - 4 \% [3].

11 червня 2017 року Україна отримала безвізовий режим із країнами $\mathrm{CC}$, що дозволило українським заробітчанам перебувати на території цих країн протягом певного часу (зазвичай 90 днів упродовж 180 денного періоду). Хоч для легальної оплачуваної роботи й потрібно оформлювати робочу візу, або мати дозвіл служби зайнятості та імміграційної служби країни-прийняття, це вплинуло на зростання кількості українців, які працевлаштувалися за кордоном.

За даними Свростату, в Європі також зростає трудова міграція. У 2018 році серед причин приїзду в країни СС 32 \% мігрантів вказали бажання влаштуватися на роботу; $26 \%$ - через сімейні обставини, $17 \%$ - отримання освіти, $24 \%$ - інші причини, включаючи міжнародний захист біженців.

Кількісно в СС частіше приїжджали: українці - 662 тис. осіб, з яких майже 88 \% працювали в Польщі; громадяни Сирії - 223 тис. осіб, з яких майже дві третини знайшли роботу в Німеччині; китайці, включаючи Гонконг - 193 тис. осіб, з яких майже половина працевлаштувалася у Великій Британії; громадяни Індії - 163 тис. осіб, з яких 44 \% також знайшли роботу у Великій Британії; жителі Сполучених Штатів Америки 147 тис. осіб, з яких більша частина працевлаштувалися у Великій Британії; громадяни Марокко - 108 тис. осіб, з яких 41 \% знайшли роботу в Іспанії; жителі Афганістану - 87 тис. осіб, з яких близько 61 \% працювали в Німеччині [4].

За даними опитування Research\&Branding Group, виїхати з України назавжди планують 1,3 млн українців, а близько 5 млн осіб збираються на тимчасове працевлаштування за кордоном [5].

Першою причиною трудової еміграції є бажання отримати за свою роботу вищу заробітну плату. Україна має низьку ціну людської праці в порівнянні з європейськими країнами (табл. 2). 
ФІНАНСОВІ РЕСУРСИ: ПРОБЛЕМИ ФОРМУВАННЯ ТА ВИКОРИСТАННЯ

Таблиця 2

Динаміка рівня оплати праџуі в окремих європейських краӥнах у 2018 рочуі

\begin{tabular}{|c|c|c|c|}
\hline Країни & $\begin{array}{c}\text { Заробітна плата } \\
\text { доподаткування, свро }\end{array}$ & $\begin{array}{c}\text { Податок із заробітної } \\
\text { плати, \% }\end{array}$ & $\begin{array}{c}\text { Заробітна плата після } \\
\text { оподаткування, свро }\end{array}$ \\
\hline Данія & 5856 & 55,8 & 2588 \\
\hline Німеччина & 4224 & 45 & 2323 \\
\hline Франція & 3872 & 45 & 1874 \\
\hline Великобританія & 3408 & 45 & 1860 \\
\hline Італія & 3264 & 43 & 1800 \\
\hline Австрія & 4000 & 55 & 1767 \\
\hline Швеція & 4128 & 57,2 & 1399 \\
\hline Іспанія & 2544 & 45 & 1114 \\
\hline Естонія & 1392 & 20 & 997 \\
\hline Чехія & 1312 & 22 & 979 \\
\hline Польща & 1216 & 18 & 950 \\
\hline Угрщина & 1152 & 15 & 775 \\
\hline Греція & 1728 & 45 & 734 \\
\hline Литва & 912 & 15 & 590 \\
\hline Румунія & 816 & 10 & 307 \\
\hline Болгарія & 656 & 10 & \\
\hline Україна & 381 & 19,5 & \\
\hline Джерел: & & & \\
\hline
\end{tabular}

Джерело: [5].

Як бачимо $з$ даних табл. 2 у Болгарії, яка посідає передостаннє місце за рівнем оплати праці заробітна плата майже вдвічі більша, ніж в Україні, а в Румунії - більша у 2,5 раза. Крім того, в Україні існує заборгованість з виплати заробітної плати, яка у 2018 році становила 2,8 млрд грн [5].

Наступною причиною трудової еміграції є нестача робочих місць та існування безробіття всередині країни. Рівень безробіття в Україні з 2000 по 2018 роки представлений у табл. 3.

Таблиця 3

Рівень безробіття в Україні з 2000 по 2018 роки

\begin{tabular}{|c|c|c|c|c|c|}
\hline Рік & $\begin{array}{c}\text { Всього } \\
\text { населення, } \\
\text { тис. осіб }\end{array}$ & $\begin{array}{c}\text { Економічно активне } \\
\text { населення, тис. осіб }\end{array}$ & $\begin{array}{c}\text { Безробітне } \\
\text { населення, } \\
\text { тис. осіб }\end{array}$ & $\begin{array}{c}\text { Рівень } \\
\text { безробіття, } \\
\text { \% }\end{array}$ & $\begin{array}{c}\text { Заресстрованих } \\
\text { безробітних, } \\
\text { тис. осіб }\end{array}$ \\
\hline 2000 & 48923,2 & 21150,7 & 2630,0 & 12,4 & 1178,7 \\
\hline 2001 & 48457,1 & 20893,6 & 2440,3 & 11,7 & 1063,2 \\
\hline 2002 & 48003,5 & 20669,5 & 2128,6 & 10,3 & 1028,1 \\
\hline 2003 & 47622,4 & 20618,1 & 1994,0 & 9,7 & 1024,2 \\
\hline 2004 & 47280,8 & 20582,5 & 1888,2 & 9,2 & 975,5 \\
\hline 2005 & 46929,5 & 20481,7 & 1595,2 & 7,8 & 891,9 \\
\hline 2006 & 46646,0 & 20545,9 & 1513,7 & 7,4 & 784,5 \\
\hline 2007 & 46372,7 & 20606,2 & 1416,7 & 6,9 & 673,1 \\
\hline 2008 & 46143,7 & 20675,7 & 1424,0 & 6,9 & 596,0 \\
\hline 2009 & 45962,9 & 20321,6 & 1956,6 & 9,6 & 693,1 \\
\hline 2010 & 45778,5 & 20220,7 & 1784,2 & 8,8 & 452,1 \\
\hline 2011 & 45633,6 & 20247,9 & 1731,7 & 8,6 & 505,3 \\
\hline 2012 & 45553.0 & 20393,5 & 1656,6 & 8,1 & 467,7 \\
\hline 2013 & 45426,2 & 20778,2 & 1576,4 & 7,7 & 487,6 \\
\hline $2014 *$ & 42928,9 & 19035,2 & 1847,1 & 9,7 & 458,6 \\
\hline 2015 & 42760,5 & 17396,0 & 1654,0 & 9,5 & 461,1 \\
\hline 2016 & 42584,5 & 17303,6 & 1677,5 & 9,7 & 407,2 \\
\hline 2017 & 42386,4 & 17193,2 & 1697,3 & 9,9 & 352,5 \\
\hline 2018 & 42153,2 & 17296,2 & 1577,6 & 9,1 & 341,7 \\
\hline
\end{tabular}

* - починаючи з 2014 року - без урахування окупованих територій Криму і Донбасу.

Джерело: [6]. 
ФІНАНСОВІ РЕСУРСИ: ПРОБЛЕМИ ФОРМУВАННЯ ТА ВИКОРИСТАННЯ

На основі даних табл. 3 видно, що за досліджуваний період рівень безробіття був найвищим в Україні у 2000 році, найнижчим - у 2007-2008 роках, а останні п’ять років тримався в межах 9,1-9,9\%.

За даними Державної служби зайнятості України на початку 2019 року навантаження офіційно зареєстрованих безробітних на одну вакансію було 4 особи. Але, як видно 3 даних табл. 3 , чисельність зареєстрованих безробітних у кілька разів менша за їх загальну кількість.

У країнах СС рівень безробіття у 2019 році становив у середньому 7,5 \%. Найнижчий рівень безробіття був у Німеччині (3,3\%), Нідерландах $(3,5 \%)$, Чехії $(1,9 \%)$. Найвищий рівень зафіксований у Греції $(18,6 \%)$ та Іспанії $(14,7 \%)$ [6]. Неможливість працевлаштування у власній країні змушує населення шукати роботу за кордоном.

Таким чином, рівень оплати праці та безробіття передусім впливають на трудовий потенціал України і країн ЄС. Цей вплив оцінюється з погляду позитивних і негативних наслідків.

Позитивним наслідком трудової еміграції для українців є можливість долучитися до європейського досвіду ведення бізнесу і після повернення із заробітків відкрити власну справу. В країнах СС кількість зайнятих у малому бізнесі становить від 70 до $90 \%$, У той час як в Україні - близько 40 \% [7].

Також позитивним наслідком $є$ переведення мігрантами значної суми заробітку до своєї країни. На сьогодні масштаби особистих переказів заробітчан часто перевищують суми міжнародних кредитних надходжень, прямих іноземних інвестицій, надходжень приватного капіталу. Розмір цих переказів впливає на фінансово-банківську систему, платіжний баланс, платоспроможний попит населення, рівень інфляції та добробут населення [12].

За останні десять років обсяг грошових переказів подвоївся. П'ятнадцять країн світу, в тому числі із п’ятьма європейськими, у 2018 році отримали понад 10 млрд дол. США кожна (табл. 4).

Таблиця 4

Динаміка обсягу грошових переказів зовнішніх мігрантів

за країнами їх найбільшого походження у 2018 роччі

\begin{tabular}{|c|c|c|c|c|}
\hline $\begin{array}{c}\text { Країна, до якої над- } \\
\text { хоять перекази від } \\
\text { мігрантів }\end{array}$ & $\begin{array}{c}\text { Обсяг переказів, } \\
\text { млрд дол. США }\end{array}$ & $\begin{array}{c}\text { Чисельність постій- } \\
\text { ного населення, тис. } \\
\text { осіб }\end{array}$ & $\begin{array}{c}\text { Сума переказів на } \\
\text { одну особу, дол. } \\
\text { США }\end{array}$ & $\begin{array}{c}\text { Частка перека- } \\
\text { зів у ВВП,\% }\end{array}$ \\
\hline Індія & 78609 & 1352642 & 58,1 & 2,9 \\
\hline КНР & 67414 & 1427648 & 47,2 & 0,5 \\
\hline Мексика & 35659 & 126191 & 282,6 & 3,0 \\
\hline Філіппіни & 33827 & 106651 & 317,2 & 10,2 \\
\hline Сгипет & 28918 & 98424 & 293,8 & 11,6 \\
\hline Франція & 26428 & 64991 & 406,6 & 0,9 \\
\hline Нігерія & 24311 & 195875 & 124,1 & 6,1 \\
\hline Пакистан & 21014 & 212228 & 99,0 & 0,8 \\
\hline Німеччина & 17364 & 83124 & 208,9 & 6,6 \\
\hline В’єтнам & 15934 & 95546 & 166,8 & 5,4 \\
\hline Бангладеш & 15496 & 161377 & 96,0 & 11,4 \\
\hline Україна & 14378 & 44246 & 325,0 & 0,9 \\
\hline Іспанія & 12301 & 46693 & 263,4 & 2,1 \\
\hline Бельгія & 11450 & 11482 & 997,2 & 1,1 \\
\hline Індонезія & 11237 & 273524 & 41,1 & \\
\hline
\end{tabular}

Джерело: [8]. 
ФІНАНСОВІ РЕСУРСИ: ПРОБЛЕМИ ФОРМУВАННЯ ТА ВИКОРИСТАННЯ

Як видно $з$ даних табл. 4 Україна в цьому списку посідає 12-е місце і за розміром переказів на одну особу поступається тільки Бельгії і Франції. Водночас тільки для економіки Сгипту частка переказів у ВВП має більше значення, ніж для економіки України. Це свідчить про низький рівень розвитку української економіки, а також значну роль зовнішньої трудової міграції для життєдіяльності українських громадян. Також в Україні, починаючи з 2009 року, сума грошових переказів 3-за кордону перевищує суму прямих іноземних інвестицій (ПІІ), таблиця 5.

Таблиця 5

Динаміка обсягу прямих іноземних інвестииї в Украӥну та грошових переказів мігрантів за 2005-2018 рр.

\begin{tabular}{|c|c|c|c|}
\hline Рік & $\begin{array}{c}\text { Обсяг прямих іноземних } \\
\text { інвестицій в Україну, } \\
\text { млрд дол. США }\end{array}$ & $\begin{array}{c}\text { Обсяг грошових переказів } \\
\text { мігрантів в Україну, } \\
\text { млрд дол. США }\end{array}$ & $\begin{array}{c}\text { Різниця між обсягами ПІІ в } \\
\text { Україну та грошових переказів } \\
\text { мігрантів, млрд дол. США }\end{array}$ \\
\hline 2005 & 7,8 & 2,4 & 5,4 \\
\hline 2006 & 5,6 & 3,1 & 2,5 \\
\hline 2007 & 9,9 & 5,3 & 4,6 \\
\hline 2008 & 10,9 & 6,8 & 4,1 \\
\hline 2009 & 4,8 & 5,9 & $-1,1$ \\
\hline 2010 & 6,4 & 6,5 & $-0,1$ \\
\hline 2011 & 7,2 & 7,8 & $-0,6$ \\
\hline 2012 & 8,4 & 8,5 & $-0,1$ \\
\hline 2013 & 4,5 & 9,7 & $-5,2$ \\
\hline 2014 & 0,4 & 7,4 & $-7,0$ \\
\hline 2015 & 2,9 & 8,5 & $-5,6$ \\
\hline 2016 & 3,3 & 9,5 & $-6,2$ \\
\hline 2017 & 2,2 & 12,1 & $-9,9$ \\
\hline 2018 & 2,4 & 16,5 & $-14,1$ \\
\hline
\end{tabular}

Джерело: розраховано авторами на основі [8; 9].

Така ситуація аналогічна в Польщі й сама по собі не є негативним або позитивним явищем. Її доцільно розглядати в сукупності всіх макроекономічних показників. Насамперед збільшення обсягу грошових переказів в Україну стимулює платоспроможний попит i, відповідно, розширення виробництва, сприяє прискореному розвитку фінансово-банківської системи.

У 2018 році перше місце за загальними обсягами переказів (з урахуванням нелегальних каналів) займала Польща, на другому місці - Росія, на третьому - США та Чеська Республіка. За даними Міністерства фінансів України, з Польщі, Росії та Чеської Республіки найбільша частка переказів надходить неформальними каналами $(93,6 ; 74,2$; 91,6 \% відповідно), що пояснюється географічною близькістю, можливостями здійснення регулярних поїздок мігрантів на батьківщину та налагодженими каналами комунікацій і передання зароблених коштів через інших осіб. Частка неформальних надходжень із Італії менша - 50,9 \%, а перекази з інших основних країн-прийняття трудових мігрантів практично всі надходять лише офіційно (США, Німеччина, Велика Британія, Кіпр, Греція) [10; 11].

Висновки та пропозиції. Фінансове забезпечення розвитку трудового потенціалу залежить від різних форм доходів, серед яких найбільш важливими є доходи від найманої праці, підприємницької діяльності у своїй країні та доходи від роботи за кордоном.

Враховуючи те, що більшість країн ЄС стимулюють трудову імміграцію, перед державою постає проблема втрати якості власного трудового потенціалу й великої кількості міграційних загроз, пов'язаних із зниженням кількості працездатного населення, зменшенням надходжень від збору податків, «відпливом мізків», непродуктивними витратами на здобуття ними освіти, тощо. 
ФІНАНСОВІ РЕСУРСИ: ПРОБЛЕМИ ФОРМУВАННЯ ТА ВИКОРИСТАННЯ

Трудова еміграція з України поступово зростає, що обумовлено низьким рівнем оплати праці всередині країни, нестачею робочих місць та існуванням безробіття, низькою якість життя, наявністю проблем з веденням приватного бізнесу.

Отже, трудовий потенціал України втрачає молодих за віком, кваліфікованих спеціалістів, що призводить до втрати трудового потенціалу країни, а також актуалізує питання збереження можливостей інноваційного розвитку національної економіки. Нині перед державою постає важливе завдання, пов'язане 3 пошуком компенсаційних механізмів збереження трудового потенціалу, вирішення якої на сьогодні перебуває саме в площині належного фінансового забезпечення.

Розв'язання глобальної задачі належного фінансового забезпечення стимулювання розвитку трудового потенціалу дозволить забезпечити збереження трудового потенціалу, а також дозволить сформувати базис для інноваційного розвитку національної економіки.

\section{Список використаних джерел}

1. Everett S. Lee. A Theory of Migration. Demography. 1966. Vol. 3. № 1. P. 47-57.

2. Мінсоцполітики: ліцензовані компанії влаштували за кордоном майже 100 тисяч мігрантів. URL: https://www.radiosvoboda.org/a/news-trudovi-mihranty/29806572.html.

3. Кваша О. С. Зовнішні міграційні процеси трудових ресурсів: фактори, стан та наслідки для України. Економіка і суспільство. 2017. № 10. С. 535-540.

4. Топ 10 європейських країн за кількістю мігрантів. URL: https:/eu.in.ua/топ-10європейських-країн-за-кількістю-м/.

5. Чотири біди бізнесу: від чого українці тікають за кордон. URL: https://minfin.com.ua/ ua/2019/11/07/39636287.

6. Рівень безробіття в Україні. URL: https://index.minfin.com.ua/ua/labour/unemploy/.

7. Як в Свропі впроваджують регулювання для бізнесу. URL: http://gk-press.if.ua/yak-uyevropi-vprovadzhuyut-regulyuvannya-dlya-biznesu/.

8. Лібанова Е. М., Фтомова О. С. Особисті перекази мігрантів: оцінка масштабів і наслідків. Демографія та соиіальна економіка. 2019. № 3(37). С. 11-29.

9. Прямі іноземні інвестиції в Україну. URL: https://index.minfin.com.ua/ua/economy/fdi.

10. Чубарь О. Г., Машко К. С. Грошові перекази трудових мігрантів в Україну: макроекономічні тенденції та регіональні особливості. Демографія та соиіальна економіка. 2019. № 3(37). C. 57-72.

11. Грошові перекази в Україну. URL: https://index.minfin.com.ua/ua/economy/transfer.

12. Шкарлет С. М. Економічна безпека підприємства: інноваційний аспект : монографія. Київ : Книжк. вид-во Нац. авіац. ун-ту. 2007. 436 с.

\section{References}

1. Everett S. Lee A. (1996). Theory of Migration. Demography, 3 (1), 47-57 [in English].

2. Minsotspolityky: litsenzovani kompanii vlashtuvaly za kordonom maizhe 100 tysiach mihrantiv [Ministry of Social Policy: licensed companies have employed almost 100,000 migrants abroad.]. Retrieved from https://www.radiosvoboda.org/a/news-trudovi-mihranty/29806572.html.

3. Kvasha, O. S. (2017). Zovnishni mihratsiini protsesy trudovykh resursiv: faktory, stan ta naslidky dlia Ukrainy [External migration processes of labor resources: factors, state and consequences for Ukraine]. Ekonomika $i$ suspilstvo - Economy and society, 10, 535-540 [in Ukrainian].

4. Top 10 yevropeiskykh krain za kilkistiu mihrantiv. [Top 10 European countries by number of migrants]. Retrieved from https://eu.in.ua/топ-10-європейських-країн/.

5. Chotyry bidy biznesu: vid choho ukraintsi tikaiut za kordon [Four troubles of business: why Ukrainians flee abroad]. Retrieved from https://minfin.com.ua/ua/2019/11/07/39636287.

6. Riven bezrobittia $\mathrm{v}$ Ukraini [Unemployment rate in Ukraine]. Retrieved from https://index.minfin.com.ua/ua/labour/unemploy.

7. Yak v Yevropi vprovadzhuiut rehuliuvannia dlia biznesu [How business regulation is being introduced in Europe]. Retrieved from http://gk-press.if.ua/yak-u-yevropi-vprovadzhuyutregulyuvannya-dlya-biznesu. 
ФІНАНСОВІ РЕСУРСИ: ПРОБЛЕМИ ФОРМУВАННЯ ТА ВИКОРИСТАННЯ

8. Libanova, E. M., Ftomova, O. S. (2019). Osobysti perekazy mihrantiv: otsinka masshtabiv i naslidkiv. Demohrafiia ta sotsialna ekonomika [Personal transfers of migrants: assessment of the scale and consequences]. Demohrafiia ta sotsialna ekonomika - Demography and social economy, 3(37), 11-29 [in Ukrainian].

9. Priami inozemni investytsii v Ukrainu [Foreign direct investment in Ukraine]. Retrieved from https://index.minfin.com.ua/ua/economy/fdi.

10. Chubar, O. H., Mashko, K. S. (2019). Hroshovi perekazy trudovykh mihrantiv v Ukrainu: makroekonomichni tendentsii ta rehionalni osoblyvosti [Remittances of labor migrants to Ukraine: macroeconomic trends and regional features]. Demohrafiia ta sotsialna ekonomika - Demography and social economy, 3(37), 57-72 [in Ukrainian].

11. Hroshovi perekazy $\mathrm{v}$ Ukrainu [Money transfers to Ukraine]. Retrieved from https://index.minfin.com.ua/ua/economy/transfer.

12. Shkarlet, S. M. (2007). Ekonomichna bezpeka pidpryiemstva: innovatsiinyi aspekt: monohrafiia [Economic security of an enterprise: an innovative aspect: monograph]. Kyiv: Natsionalnyi aviatsiinyi universytet [in Ukrainian].

Мекшун Людмила Миколаївна - кандидат економічних наук, доцент, доцент кафедри управління персо-

налом та економіки праці, Чернігівський національний технологічний університет (вул. Шевченка, 95, м. Чернігів, 14035, Україна).

Мекшун Людмила Николаевна - кандидат экономических наук, доцент, доцент кафедры управления персоналом и экономики труда, Черниговский национальный технологический университет (ул. Шевченко, 95 , г. Чернигов, 14035, Украина).

Mekshun Liudmyla - PhD in Economics, Associate Professor, Associate Professor of Personnel Management and Labor Economics, Chernihiv National University of Technology (95 Shevchenka Str., 14035 Chernihiv, Ukraine).

E-mail: ludmila.mek1966@gmail.com

ORCID: https://orcid.org/0000-0002-8384-5214

ResearcherID: B-1484-2017

Забаштанський Максим Миколайович - доктор економічних наук, професор, директор навчальнонаукового інституту бізнесу, природокористування і туризму, Чернігівський національний технологічний університет (вул. Шевченко, 95, м. Чернігів, 14035, Україна).

Забаштанский Максим Николаевич - доктор экономических наук, профессор, директор учебно-научного института бизнеса, природопользования и туризма (ул. Шевченко, 95, г. Чернигов, 14035, Украина).

Zabashtanskyi Maksym - Doctor of Economics, Professor, Director Educational-Scientific Institute of Business,

Environtal Management and Tourism, Chernihiv National University of Technology (95 Shevchenka Str., 14035

Chernihiv, Ukraine).

E-mail: mazani@ukr.net

ORCID: http://orcid.org/ 0000-0002-8966-8116

ResearcherID: G-6145-2014

Мекшун Л., Забаштанський М. Фінансове забезпечення стимулювання розвитку трудового потенціалу в умовах активізації міграційних процесів. Проблеми і перспективи економіки та управління. 2020. № 1 (21). С. 229-237. 